\title{
Recent Microfluidic Innovations for Sperm Sorting
}

\author{
Maedeh Khodamoradi ${ }^{1}$ (D), Saeed Rafizadeh Tafti ${ }^{1}$ (D), Seyed Ali Mousavi Shaegh ${ }^{2,3,4} \mathbb{( D D}$, Behrouz Aflatoonian ${ }^{1,5,6,7}$, \\ Mostafa Azimzadeh $1,5,6, *$ (D) and Patricia Khashayar $8, *$ (D)
}

1 Medical Nanotechnology \& Tissue Engineering Research Center, Yazd Reproductive Sciences Institute, Shahid Sadoughi University of Medical Sciences, Yazd 89195999, Iran; m.khodamoradi95@gmail.com (M.K.); srafizadeh2000@gmail.com (S.R.T.); b.aflatoonian@ssu.ac.ir (B.A.)

2 Laboratory for Microfluidics and Medical Microsystems, Bu Ali Research Institute, Mashhad University of Medical Sciences, Mashhad 9196773117, Iran; mousavisha@mums.ac.ir

3 Clinical Research Unit, Ghaem Hospital, Mashhad University of Medical Sciences, Mashhad 9179919966, Iran

4 Orthopedic Research Center, Mashhad University of Medical Sciences, Mashhad 9179919966, Iran

5 Stem Cell Biology Research Center, Yazd Reproductive Sciences Institute, Shahid Sadoughi University of Medical Sciences, Yazd 89195999, Iran

6 Department of Advanced Medical Sciences and Technologies, School of Paramedicine, Shahid Sadoughi University of Medical Sciences, Yazd 8916188635, Iran

7 Department of Reproductive Biology, School of Medicine, Shahid Sadoughi University of Medical Sciences, Yazd 8915173143, Iran

8 Center for Microsystems Technology, Imec and Ghent University, 9050 Ghent, Belgium

* Correspondence: m.azimzadeh@ssu.ac.ir (M.A.); patricia.khashayar@ugent.be (P.K.); Tel.: +98-9123686413 (M.A.); +32-487160656 (P.K.)

check for updates

Citation: Khodamoradi, M.; Rafizadeh Tafti, S.; Mousavi Shaegh, S.A.; Aflatoonian, B.; Azimzadeh, M.; Khashayar, P. Recent Microfluidic Innovations for Sperm Sorting. Chemosensors 2021, 9, 126. https:// doi.org/10.3390/chemosensors9060126

Academic Editor: Stéphane Le Calvé

Received: 15 April 2021

Accepted: 28 May 2021

Published: 1 June 2021

Publisher's Note: MDPI stays neutral with regard to jurisdictional claims in published maps and institutional affiliations.

Copyright: (C) 2021 by the authors. Licensee MDPI, Basel, Switzerland. This article is an open access article distributed under the terms and conditions of the Creative Commons Attribution (CC BY) license (https:/ / creativecommons.org/licenses/by/ $4.0 /)$.

\begin{abstract}
Sperm selection is a clinical need for guided fertilization in men with low-quality semen. In this regard, microfluidics can provide an enabling platform for the precise manipulation and separation of high-quality sperm cells through applying various stimuli, including chemical agents, mechanical forces, and thermal gradients. In addition, microfluidic platforms can help to guide sperms and oocytes for controlled in vitro fertilization or sperm sorting using both passive and active methods. Herein, we present a detailed review of the use of various microfluidic methods for sorting and categorizing sperms for different applications. The advantages and disadvantages of each method are further discussed and future perspectives in the field are given.
\end{abstract}

Keywords: microfluidics; lab-on-a-chip; sperm sorting; fertility

\section{Introduction}

Microfluidics and lab-on-a-chip devices play important roles in biology and medicine. Owing to their micron-sized features, such devices are not only capable of processing samples at low volumes (mL to $\mathrm{nL}$ ) [1] but also allow for the possibility of sample manipulation in the microchannels. Microfluidic platforms enable various tests in a fast and low-cost fashion, using miniaturized or portable devices. This is of great importance for applications, such as single-cell analysis, drug encapsulation, drug and toxicity testing, separation and detection of biomarkers, and cell sorting [2-6]. The latter has attracted more attention recently due to the microfluidic systems' high precision and ease of performing steps, such as culturing, mixing, labeling, attachment to nano- and micro-particles, immune- or aptamer-based capturing, and separation of cells and stem cells. In addition, microfluidic systems can also provide platforms for studying the effects of chemical, physical, and mechanical stimuli on the cells, as well as advanced omics and metabolite analysis [5,7-10].

Infertility is a major healthcare problem, which affects $8-12 \%$ of couples worldwide. An important issue during conception is the selection of the best gametes. Scientists have been trying for years to enhance the chance of conception using various approaches [11,12]. Sperm, known as the male gamete and produced through gametogenesis in mammalians, plays a vital role in transferring the genetic materials of the father to the offspring. Following 
fertilization, the proteome of an oocyte cytoplasm is reprogrammed to start cell division and embryogenesis [13-15]. The generation of the mammalian gametes, which are derived from a founder population of primordial germ cells (PGCs), is determined early during the embryogenesis before they start their unique development process [16-18].

In vivo, the mammalian spermatozoa undergo an intense process during their migration through the female reproductive tract [19]. The passage of sperm through this tract is therefore regulated to ensure only sperms with normal morphology and vital motility will succeed $[20,21]$. The obstacles in the way of sperms before fertilizing an oocyte are the dynamics of sperm transport, entry, and distribution in the vagina, cervix, uterus, uterotubal junction, sperm storage reservoirs [20], cumulus cells [22-24], and zona pellucida $[25,26]$. Successful fertilization, however, requires high-quality sperm to survive this process [27]. This is defined by a number of factors, including the proportion of viable and motile sperms and their swimming speed, the number of structurally normal and acrosome-intact sperms, the sperms' capacitation ability, and the morphology and relative dimensions of their different components. Discussing these values, however, is out of the scope of this article but could be found in fertility guidelines [28,29]. In this regard, the evaluation and sorting of sperms are essential to the success of assisted reproductive technology (ART) [30,31]. In other words, it is of utmost importance to perform efficient sorting to achieve a sufficient population of morphologically normal and motile sperms with uncompromised DNA integrity and acrosome state [32-34].

To mimic the natural sperm selection strategies in ART and to improve its quantity and quality, several advanced methods are developed [12]. These methods are mainly used for sperm selection prior to intra-cytoplasmic spermatozoa injection (ICSI), which was conventionally performed by a clinical embryologist. Some examples of these methods include surface charge selection, hyaluronic acid binding, sperm apoptosis assay, sperm birefringence, intra-cytoplasmic morphologically selected sperm injection (IMSI), motile sperm organelle morphology examination, DNA/chromatin integrity, hypo-osmotic swelling test (HOST), Raman spectroscopy [20,35], and zona-binding sperm selection [25]. This is because the use of microfluidic devices for sperm processing in the past decade has created new opportunities for the field [36].

Microfluidics was adopted for ART purposes in the 2000s [37]. Ever since, it has helped to improve ART results by facilitating different steps, such as embryo culture [38], the trapping and characterization of human oocytes [38,39], in vitro fertilization (IVF) [38], reduction of polyspermic penetration during IVF [40], removal of the zona pellucida from mammalian embryos [41], removal of cumulus from mammalian zygotes [42], sperm monitoring, and finally, sperm sorting [43-51].

Microfluidic-based sperm sorting is an important cell-sorting category that is emerging very fast. In fertility studies, as well as infertility treatments, sperm sorting is a crucial step in which viable, motile, and morphologically appropriate sperm cells should be separated from the semen or washed sperm samples for fertilization [3,4,52]. Implementing these steps in a microfluidic platform, as mentioned earlier, enables the completion of various tests in a fast and low-cost fashion, with a lower amount of the target fluid needed and using miniaturized or portable devices. This article reviews recent advancements in the development of microfluidic devices for sperm sorting in three subsections: (i) passive methods (geometry- and rheotaxis-based approaches, fluid flows); (ii) active methods (acoustic waves, chemotaxis, and thermotaxis); (iii) point-of-care (POC) devices. The latter is discussed in a separate section because of their importance in the diagnosis and treatment of infertility and sperm analysis.

\section{Microfluidic Sperm-Sorting Techniques}

Microfluidic platforms for sperm sorting rely on either active or passive methods. In active methods, external stimulators, such as the temperature of chemical gradients or an active fluid flow, perform the sorting, while passive methods rely on the inherent behavior and movement of sperms in the absence of any external stimuli. As part of the design 
considerations, a microfluidic sorter needs to be safe for sperms such that it will not alter their specifications, such as motility, morphology, DNA integrity, and acrosome. This can be achieved using channels and chambers with sperm-friendly size, length, shape, and coatings. These features can be different in each study according to the specific application and sorting strategy of the designed chip for sperm sorting [1,3]. Similarly, the employed forces and stimuli, such as acoustic waves, chemicals, heat, and electric charges, should not have any negative impact on the sperms, their activities, or the medium surrounding them. Such safety concerns should be taken into consideration also regarding coloring dyes and/or tracking tags used for sperm analysis and imaging purposes inside the microfluidic devices [53-55]. On the other hand, as the passive methods are mainly based on the macroscopic morphology and displacement of the sperms, they provide a safer and less invasive sorting approach compared to the active methods. However, they are less capable of benefiting from specific sperm behaviors/characteristics [56-58].

In the following section, the most popular active and passive approaches are discussed, and finally, some innovative future directions are explained.

\subsection{Passive Methods}

Passive strategies that were developed for sorting high-quality sperms in microfluidic platforms are summarized in Table 1.

\subsubsection{Geometry and Chip Design}

Imitating the natural path of sperms through the female reproductive tract is identified as a promising strategy for selecting high-quality sperms. The oviduct and uterotubal junction are the main regions involved in sperm selection [59]. Thus, many researchers have grasped the importance of mimicking these folded regions by introducing various microfluidic chip designs with decorated channels and micro-confined geometries to passively select high-quality sperms $[31,57,60]$. Moreover, some studies have revealed fluid shears in a well-organized fluid flow, where specific hydrodynamic interactions take place, to be essential for external fertilization. Therefore, the following specific designs in the microfluidic chips can help with an appropriate simulation of mechanical fluid and hydrodynamic interaction through the external fertilization process [61]. Moreover, the use of such passive selection strategies can help to eliminate harmful centrifugation steps, reduce sorting time, and prevent DNA fragmentation and reactive oxygen species (ROS) formation.

In this regard, a micro-pillar chip was designed based on the filtering characteristics of the female reproductive tract for the noninvasive sorting of high-quality sperms [62] (Figure 1A). The results revealed that adopting simple periodic arrays or trapping and isolation (SPARTAN) in the microfluidic channels significantly enhanced the morphology, nuclear maturity, and DNA integrity of the sorted sperms. Using this technique, over $99 \%$ of the motile sperms were selected in ten minutes, showing that this novel device could provide a rapid one-step self-sorting strategy without any need for the time-consuming preparation steps, such as semen washing and centrifuging.

Passive microfluidics was also used for good quality sperm sorting in zebrafish. This is because many studies have highlighted that the sperms of some marine animals, such as zebrafish, do not follow physical and chemical stimuli, such as temperature gradients, specific chemical concentrations, or rheotaxic behaviors, to reach the eggs [63]. As illustrated in Figure 1B, geometrical micro-confinements inside the microfluidic channels of a baffle-based system produced flow-induced shear forces. The generated velocity shear gradients caused lateral migration of the activated zebrafish sperms toward the stagnation for progressive motile sperm retrieval [64]. Using this technique, a $44 \%$ improvement in sperm-retrieval efficiency was reported. Furthermore, $80 \%$ of the total sperm population migrated to the retention zone when the fluid rate was optimized to $0.7 \mu \mathrm{L} / \mathrm{min}$. This shows that the migration behavior of sperms is highly affected by the hydrodynamic profile 
of the flow through the microchannels. This method has the potential to be further adopted for the passive collection of the progressive motile sperms in mammalian species.

Apart from the flow profile, implementing specific geometries in the sperm migration passage that were inspired by the natural sperm sorting process for both internal and external fertilization in mammalian and marine animals may provide low-cost and noninvasive solutions for selecting high-quality sperms based on their motility behavior. For example, a butterfly-shaped stricture in which the width of the channel varied between $40 \mu \mathrm{m}$ and $300 \mu \mathrm{m}$ to mimic the anatomy of junctions in the female reproductive tract was fabricated and tested (Figure 1C). This specific channel geometry simulated a natural sperm-sorting process based on the motility behavior of sperms and revealed the sperm locomotion in the channels, as well as their motility-based competition. It was also shown that the gate-like strictures had a significant effect on sorting the sperms based on their motility behavior. This is because highly motile sperms, unlike non-motile and slower sperms, swim close to each other and accumulate near the strictures because of their tendency toward walls and solid boundaries. Then, depending on the flow feature and the shear rate at the strictures, those sperms that are slower than the velocity threshold accumulate in front of the stricture and fail to swim to the fertilization site. However, the highly progressive motile sperms swim to the fertilization site, where the motility-based competition occurs [65].

\subsubsection{Rheotaxis}

Oviductal fluid secretion from the female reproductive tract plays a key role in guiding sperms toward the egg, influencing the fertilization rate through affecting the viscosity gradient and flow $[31,66]$. In this regard, rheotaxis acts as the key mechanism responsible for directing sperms toward the oocyte against the fluid flow [67]. It offers advantages, such as a longer exposure time to various stimuli during the sperm migration path compared to other mechanisms, such as chemotaxis and thermotaxis [68].

Several microfluidic devices with various microchip designs have thus enabled sperm sorting based on sperm rheotactic behavior and upstream swimming of sperms in a fluid flow [69]. Mimicking the fluid flow conditions of the female reproductive tract in such microfluidic devices through precise control of the flow rate in the microchannels is considered a promising strategy to select high-quality and progressive motile sperms. In this regard, a high-throughput sperm-sorting device was developed by embedding corrals inside a microchannel to trap and isolate normal and progressive motile sperms (Figure 1D) [70]. In this tool, the sperm movement was simulated for different flow rates by means of the finite element method (FEM) and adopting appropriate seminal injection rates through the microfluidic device to investigate how they can trigger the rheotactic behavior of the sperms in the vicinity of corrals. The results showed that progressive motile sperms with velocities of $51-82 \mu \mathrm{m} / \mathrm{s}$ in human samples and $48-93 \mu \mathrm{m} / \mathrm{s}$ in bovine seminal samples were isolated within the corrals. Moreover, adding the corral-shaped structures in the sperm retainer enhanced the residence time of motile sperms from $12 \mathrm{~s}$ to $45 \mathrm{~min}$. Thus, this passive device provided a noninvasive approach for the effective separation of motile sperms based on their rheotactic behavior and injection flow rate.

In another attempt, an automated microfluidic device was developed that utilized gravity for passive liquid feeding to create a fluid flow without any need for an additional pump [71]. In this device, the rheotaxis mechanism was a promising strategy for sorting the motile sperms by inducing their upstream swimming tendencies (Figure 1E). The sorting process started with automated semen injection. Suctioning of the sorted motile sperms, which highly affects the efficiency of the system, was performed using a motor-derived cam pipette controller mounted on the top of the device. The performance was optimized by altering the suctioning delay time based on the motility factors, such as mean velocity, motility percentage, and motile sperm rate, in sorted canine seminal samples. The highest efficiency was reported after an $80 \mathrm{~s}$ delay following semen injection; this is quick since the conventional methods require about $1 \mathrm{~h}$ to select the motile sperms. 
A diffuser-type microfluidic device is another example that was fabricated based on an initial numerical simulation and rheotaxis of sperms [72]. The device benefited from a novel image processer that analyzed the video of the samples without any need for sperm pretreatment with fluorescent dyes. As Figure 1F illustrates, by increasing the width of the diffuser-type channel, the fluid velocity gradually decreased. Hence, the rheotactic behavior of the sperms was initiated at the diffuser region, where they had the slowest velocity (zone C). Furthermore, the majority of the progressive canine motile sperms migrated to zone A, while the others remained in zones B and C. The findings revealed that a double wash with the Dulbecco's phosphate-buffered saline (DPBS) could help with separating the irrelevant components from the sorted motile sperms, significantly increasing the motility percentage and motile sperm rate to $82.24 \%$ and $53.10 \%$, respectively. Furthermore, in comparison with conventional sorting strategies, this novel microfluidic device had a high sorting throughput of up to $8.6 \times 10^{5}$ sperms $/ \mathrm{min}$.

These examples of passive microfluidic devices show that taking advantage of the movement direction and orientation of sperms in a liquid flow [67], along with mimicking the microenvironment of the female reproductive tract, such as embedding ciliated and secretory cells [73] in microdevices, could help with the efficient sorting of high-quality motile sperms, thereby leading to a higher fertilization rate. Additionally, these tools can also help to eliminate the drawbacks of conventional motile-sperm-separation strategies, such as DNA fragmentation and ROS formation, because harmful centrifuging steps can be omitted in automated and passive microfluidic-based techniques [70].

\subsubsection{Fluid Flows}

The hydrostatic pressure and capillary forces can help to generate the required liquid flow in the microchannels for the active and noninvasive separation of motile sperms based on their ability to swim across the laminar flow streamlines. This approach mimics the natural behavior of the spermatozoa in the female reproductive tract after passing through various fluids with different dynamics and breaking several boundaries to successfully fertilize an oocyte [66,73]. Thus, focusing on these characteristics has motivated many researchers to enhance ART by increasing the sorting throughput of highly motile and functional sperms [56].

In the natural conception process, progressive motile sperms advance toward the oocyte by freely swimming through different fluid flows in the viscous female reproductive tract [74]. Considering the capability of motile sperms to cross laminar streamlines, various microfluidic devices used capillary forces and hydrostatic pressure as external forces to actively isolate highly motile sperms from other cells and irrelevant particles in a seminal sample [75]. In other words, the variations in the fluidic environment are considered as flow boundaries for non-motile and abnormal sperms [73]. Therefore, by imitating these features in a microfluidic environment, the risk of sperms being damaged is reduced and high-quality and motile sperms can be separated based on their motility rate.

As the first example, in a microfluidic chip, three different parallel flows were utilized in a microfluidic chip to sort motile sperms, leading to a higher sperm activity of $95.7 \%$ compared with the controls (87.2\%) [76]. As shown in Figure 2A, the motile sperms from the upper and lower inlets crossed the laminar streamline and were restored in the collection reservoir. The results indicated that lower seminal flow rates (within the range of $50-100 \mu \mathrm{m} / \mathrm{s}$ ) were associated with a more efficient sorting process due to an increased swimming time in the main channel, and thus more motile sperms found the opportunity to migrate toward the media flow.

Another functional diffuser-type microfluidic sperm sorter (DMSS) was able to sort progressively motile and high-DNA-integrity spermatozoa (Figure 2B) [77]. The specific geometry of the microchannels in this device allowed for the cross transport of spermatozoa through the laminar streamlines. This tool also revealed that functional sperms could be characterized based on their sinusoidal trajectory patterns, which results in a higher fertility potential compared with the linear and non-sinusoidal ones. Hence, the motility pattern 
and associated kinetics play a crucial role in identifying the most competent sperms. In addition, when using this tool, a significant improvement in DNA integrity $(95 \%)$ and lower DNA fragmentation to $18.4-21.9 \%$ was noted.

Table 1. Summary of passive strategies applied in microfluidic chips.

\begin{tabular}{|c|c|c|c|c|c|}
\hline $\begin{array}{l}\text { Sorting } \\
\text { Strategy }\end{array}$ & Parameter(s) & Advantages & Disadvantages & Significance & Ref. \\
\hline \multirow{3}{*}{ Geometry } & $\begin{array}{l}\text { Swimming behavior of } \\
\text { sperms, micro-pillar } \\
\text { arrays }\end{array}$ & $\begin{array}{l}\text {-Noninvasive } \\
\text {-Reduced complexity of } \\
\text { structural features } \\
\text {-Mimics filtering } \\
\text { characteristics of female } \\
\text { reproductive tract }\end{array}$ & $\begin{array}{l}\text {-Complicated chip } \\
\text { fabrication process due to } \\
\text { complex high-aspect-ratio } \\
\text { geometry }\end{array}$ & $\begin{array}{l}\text {-Morphology: 5-fold } \\
\text { enhancement } \\
\text {-Nuclear Maturity: 3-fold } \\
\text { enhancement } \\
\text {-DNA integrity: 2-4-fold } \\
\text { enhancement } \\
\text {-Throughput: } 99 \% \\
\text {-Working time: } 10 \mathrm{~min}\end{array}$ & {$[62]$} \\
\hline & $\begin{array}{l}\text {-Velocity shear gradient } \\
\text {-Hydrodynamic profile of } \\
\text { fluid micro-confinement }\end{array}$ & $\begin{array}{l}\text {-Simple working } \\
\text { procedure }\end{array}$ & $\begin{array}{l}\text {-Complicated chip design } \\
\text { and fabrication due to } \\
\text { complex high-aspect-ratio } \\
\text { geometry }\end{array}$ & $\begin{array}{l}\text {-Retrieval efficiency: } 44 \% \\
\text { increased } \\
\text {-Throughput: } 80 \% \\
\text {-Optimized flow rate: } \\
0.7 \mu \mathrm{L} / \mathrm{min}\end{array}$ & [64] \\
\hline & $\begin{array}{l}\text {-Hydrodynamic profile of } \\
\text { fluid within the channel } \\
\text {-Fluid flow mechanics } \\
\text {-Shear rate } \\
\text { butterfly-shape structure }\end{array}$ & $\begin{array}{l}\text {-Mimics the variable } \\
\text { width of the junctions } \\
\text { within the female } \\
\text { reproductive tract } \\
\text {-Simple chip design and } \\
\text { fabrication }\end{array}$ & $\begin{array}{l}\text {-Accumulation of a large } \\
\text { population of sperms in } \\
\text { front of the stricture leads } \\
\text { to reduced efficiency of } \\
\text { sorting highly motile } \\
\text { sperms }\end{array}$ & $\begin{array}{l}\text {-Highly progressive motile } \\
\text { sperms swim to the } \\
\text { fertilized site } \\
\text {-Non-motile and slow } \\
\text { sperms accumulate in front } \\
\text { of the stricture }\end{array}$ & {$[65]$} \\
\hline \multirow{3}{*}{ Rheotaxis } & $\begin{array}{l}\text {-Rheotactic behavior of } \\
\text { sperms } \\
\text {-Corrals inside } \\
\text { microchannels } \\
\text {-Flow rate }\end{array}$ & -Adding sperm retainer & $\begin{array}{l}\text {-Complicated chip } \\
\text { fabrication due to complex } \\
\text { high-aspect-ratio geometry }\end{array}$ & $\begin{array}{l}\text {-Throughput: } 100 \% \\
\text {-Residence time: } 45 \mathrm{~min}\end{array}$ & {$[70]$} \\
\hline & $\begin{array}{l}\text {-Fluid flow } \\
\text {-Rheotactic behavior of } \\
\text { sperms } \\
\text {-Gravity }\end{array}$ & $\begin{array}{l}\text {-Automated procedure } \\
\text {-Fast sorting } \\
\text {-Eliminate the use of } \\
\text { additional tools, such as a } \\
\text { pump } \\
\text {-Simple chip design and } \\
\text { fabrication }\end{array}$ & $\begin{array}{l}\text {-Misses some of the } \\
\text { potentially high-quality } \\
\text { sperms due to the rapid } \\
\text { pace }\end{array}$ & $\begin{array}{l}\text {-Optimized delay time } \\
\text { between semen injection } \\
\text { and suctioning motile } \\
\text { sperms: } 80 \mathrm{~s} \\
\text {-Highest figures of motility } \\
\text { indexes are mean velocity: } \\
8.94 \% \text {, motility percentage: } \\
32.58 \% \text {, motile sperm rate: } \\
21.99 \%\end{array}$ & [71] \\
\hline & $\begin{array}{l}\text {-Fluid velocity inside the } \\
\text { channel } \\
\text {-Designing a diffuser-type } \\
\text { channel }\end{array}$ & $\begin{array}{l}\text {-Simple chip design and } \\
\text { fabrication } \\
\text {-Performance based on } \\
\text { continuity equation in } \\
\text { fluid dynamics }\end{array}$ & $\begin{array}{l}\text {-Imprecise collection of } \\
\text { sorted sperms in } \\
\text { appropriate region }\end{array}$ & $\begin{array}{l}\text {-Throughput: } \\
8.6 \times 10^{5} \text { sperms } / \mathrm{min} \\
\text {-Working time: } 10 \mathrm{~min} \\
\text {-\%Motility: } 82.24 \% \\
\text {-Motile sperm rate: } 53.10 \%\end{array}$ & [72] \\
\hline \multirow[b]{2}{*}{ Fluid Flow } & $\begin{array}{l}\text {-Three different parallel } \\
\text { laminar flows } \\
\text {-Variable semen flow rate } \\
\text { - Ability of sperms to } \\
\text { cross streamlines in } \\
\text { laminar flow }\end{array}$ & $\begin{array}{l}\text {-Mimic viscous } \\
\text { environment of female } \\
\text { reproductive tract } \\
\text {-Simple chip design and } \\
\text { fabrication }\end{array}$ & $\begin{array}{l}\text {-Missing some of } \\
\text { potentially high-quality } \\
\text { sperms due to time } \\
\text { dependency of migration in } \\
\text { laminar fluid }\end{array}$ & -Sperm activity: 95.7\% & {$[76]$} \\
\hline & $\begin{array}{l}\text {-Diffuser-type channel } \\
\text {-Fluid dynamics } \\
\text { production } \\
\text {-Enabling cross-passage } \\
\text { of sperms through } \\
\text { laminar flow streamline }\end{array}$ & $\begin{array}{l}\text {-Continuity equation in } \\
\text { fluid dynamics }\end{array}$ & $\begin{array}{l}\text {-Complicated chip design } \\
\text { and fabrication due to } \\
\text { complex high-aspect-ratio } \\
\text { geometry }\end{array}$ & $\begin{array}{l}\text {-Motility pattern of more } \\
\text { functional sperms: } \\
\text { sinusoidal trajectory } \\
\text { pattern } \\
\text {-DNA integrity: } 95 \% \\
\text {-DNA fragmentation: } \\
18.4-21.9 \%\end{array}$ & [77] \\
\hline
\end{tabular}



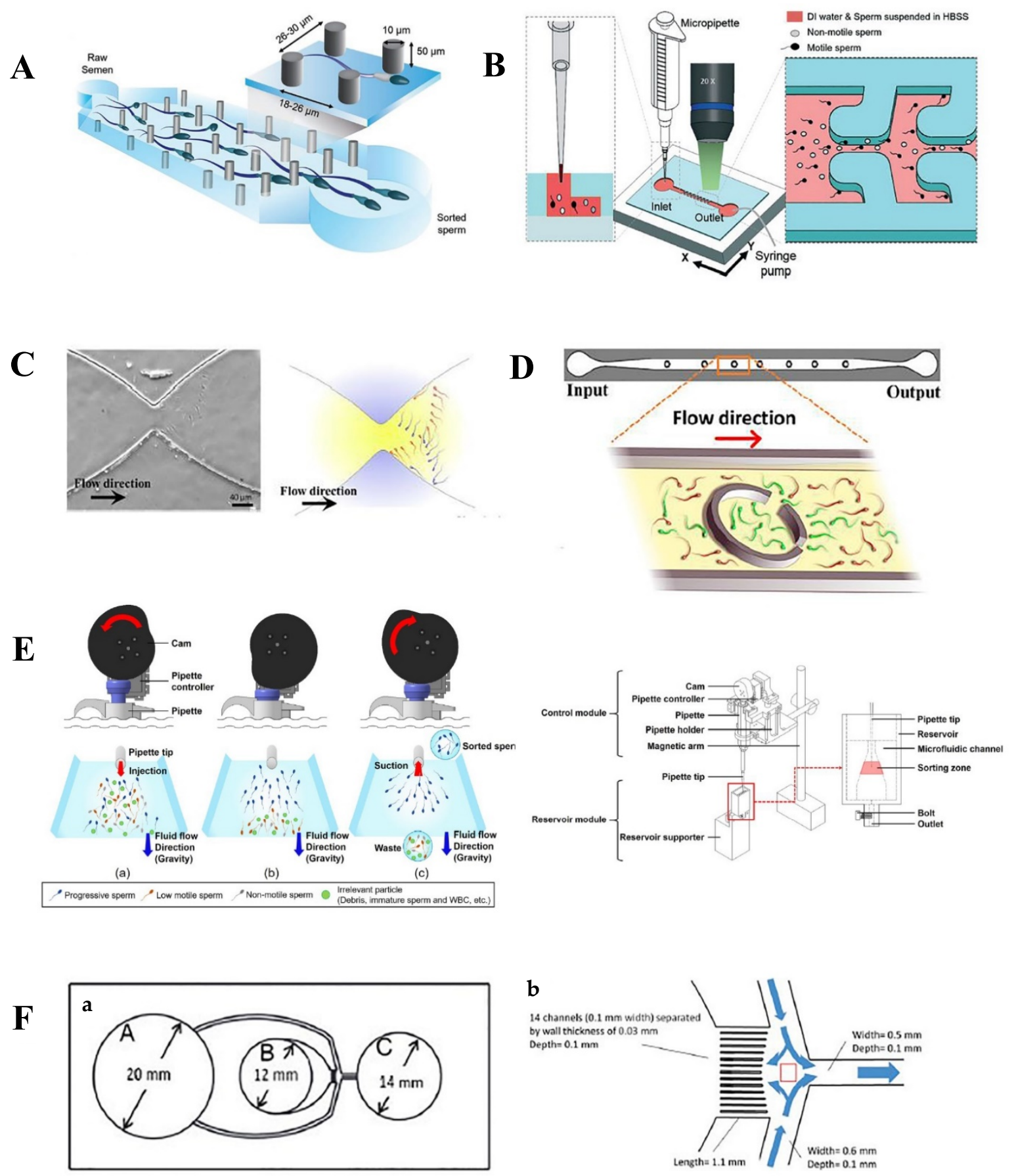

Figure 1. Passive microfluidic chips for sperm sorting. (A) Micro-pillar arrays imitate the filter-like characteristics of the female reproductive tract [62]. (B) Geometrical micro-confinement in the side channels of the microfluidic device guides the activated sperms toward the stagnation zone [64]. (C) The stricture inside the microfluidic channel mimics the variable width of the junctions within the female reproductive tract [65]. (D) Embedded corral-shaped structures inside the microchannel that isolate normal and progressive motile sperms from a seminal sample [70]. (E) Automated sperm pipetting activated using a motor-derived cam based on the rheotactic behavior of sperms in fluid flow prepared by means of the gravity force to separate progressive motile sperms [71]. (F) A diffuser-type microfluidic sperm sorter (DMSS) works based on the sperms' ability to break the laminar flow streamline: (a) sorting medium (chamber A), semen seeding (chamber B), and motile sperms reservoir (chamber C); (b) the specific geometry of the chip manipulates the fluid dynamics inside the channels [77]. Figures reprinted with permissions. 


\subsection{Active Methods}

Recent active strategies that have been applied in microfluidic devices to sort the high-quality and progressive motile sperms are summarized in Table 2.

\subsubsection{Acoustic Waves}

The incorporation of acoustic fields within the microfluidic devices has created an enabling platform for the high-throughput sorting of motile and functional sperms. The low energy intensity of an acoustic field inhibits or minimizes possible damage to DNA and the cell membrane while establishing precise control over the isolation of sperms with desired characteristics. Sperm sorting using acoustic waves can be modulated based on the sperms' sizes and motility patterns [78].

Acoustic waves employed in the microfluidic chips can be classified into (1) bulk acoustic (BAW) and (2) surface acoustic (SAW) waves [79]. In BAW, the compressional waves are generated within a piezoelectric material located close to the microchannel in a way that matches the resonant frequency of the fluid inside the microchannel, forming acoustic waves in the bulk fluid. SAW, on the other hand, are generated using a series of interdigitated transducers over a flat surface. In this way, the acoustic waves are propagated inside and on the surface of the piezoelectric transducers, thereby avoiding the need for fluid resonance excitation $[80,81]$.

In this regard, surface acoustic waves were used to isolate high-DNA-integrity and morphologically normal bull's sperms based on their size and degree of motility in a continuous flow condition [78]. The isolation time was reduced to about $50 \mathrm{~min}$ with a clinically efficient output of over 60,000 selected sperms per processing cycle. As shown in Figure $2 \mathrm{C}$, the acoustic field was applied on the seminal flow with a $30^{\circ}$ angle to trap the desired sperms and orient their swimming direction toward the lateral laminar buffer flow for final collection. In comparison with the original sample, the isolated sperms had a high vitality of $50 \%$, along with high progressive motility of $60 \%$. Moreover, they expressed higher DNA integrity (over $38 \%$ ), as well as a $64 \%$ increase in their swimming velocity.

Compared with SAW, BAW operates at a narrower range of sound wave frequencies (from 0.1 to $10 \mathrm{MHz}$ ) [82]. This approach induces a lower energy transfer to the biological samples and thus has attracted the attention of many researchers for purposes such as isolating sperm cells from female DNA samples, particularly for criminal assault investigations [83]. This is why the number of sperm cells is low compared with female DNA samples in the majority of the mock sexual assault samples. A novel polymeric bead-assisted acoustic trapping strategy was used to collect sperms in $15 \mathrm{~min}$ using a microfluidic platform [84]. In this technique, an acoustic node is formed due to the pressure distribution created by the incoming and reflected sound wave resonation. The acoustic node represents a zero-pressure region; hence, the biological particles or the cells are not damaged in this trapping cavity. Figure 2D shows that adding polystyrene beads with the same size as the sperms helps with the efficient aggregation of beads and sperms in the trapping nodes, even when the number of sperms is scarce. This modification also increased the efficiency of sperm isolation from 18 to $85 \%$. It can therefore be concluded that the acoustic separation strategy in a microfluidic device offers several benefits, such as isolation of small amounts of intact sperms from a mixture of DNA and epithelial cells in a very short timeframe. Moreover, the elimination of several washing and centrifugation steps, along with the physical separation of sperms from a vaginal swab, makes this strategy a promising and precise method in sexual assault investigations.

\subsubsection{Chemotaxis and Thermotaxis}

Spermatozoa react to thermotaxis and chemotaxis signals in active strategies in order to reach the oocyte at the fertilization site. In other words, chemotaxis and thermotaxis are two major mechanisms that guide the capacitated and ready-to-fertilize spermatozoa toward the oocyte in the fallopian tube at the time of ovulation [85-87]. Thermotaxis has a higher influence on the sperm guidance process as it facilitates the sperm movement 
from a cold isthmic reservoir to the warm fertilization site at the end of the oviduct. While this process includes a relatively long-distance migration of the sperms, chemotaxis contributes to the final but short guidance path of the capacitated spermatozoa to fertilize the egg. The concentration gradient of particular chemical substances at the proximate vicinity of the oocyte and within the cumulus cells of the oocyte act as a chemoattractant. Some of the confirmed chemoattractants in the follicular fluid include progesterone, atrial natriuretic peptide (ANP), and acetylcholine (Ach), which attract the sperms at pico- and nanomolar concentrations.

In recent years, microfluidic technologies have enabled precise control over the chemoattractant and temperature gradient in various sperm-sorting studies [88,89]. They not only help to imitate the natural ovulation process but also enable superior control over the biochemical concentration and temperature gradient along the microchannels $[86,87]$.

A flow-free microfluidic chip was designed, for instance, to investigate the effect of a gradient in the concentration of progesterone as a chemoattractant in follicular fluid on the sperm selection process [87]. The device was made of gelatin/agarose hybrid hydrogel to enhance sperm viability. It was operated using a $1.0 \mu \mathrm{M}$ progesterone concentration, which is approximately similar to the concentration found in the vicinity of cumulous cells (Figure 3A). The results indicated an enhanced sperm chemotactic ratio (1.41) for samples exposed to the progesterone gradient compared with the controls (1.09). Thus, the physiological concentration of progesterone was reported to have a significant influence on spermatozoa. In another study, a chemotaxis-based microfluidic device was developed using acetylcholine (Ach) as a putative chemoattractant and rat oviductal fluid, which is also a mixture of various chemoattractants [90]. The device managed to establish a uniform concentration gradient of chemical substrates in a stationary fluidic environment. Thus, the competent sperms were selected based on their chemotactic behavior rather than rheotactic and chemokinetic behaviors. Figure 3B shows the time-invariant linear concentration profile ranging from 0 to $1 \mathrm{~mol} / \mathrm{m}^{3}$ in the transverse channels. The results demonstrated an approximately $20 \%$ improvement in the number of entered sperms with increasing Ach concentration. However, no such significant improvement was noted in the absence of Ach or in the presence of a uniform concentration of the chemoattractant. This is while about $8.5 \%$ of the rat sperm's population showed a chemotactic behavior in an Ach-filled environment in which the sperms migrated toward the higher gradient of the chemoattractant; this rate was reported to be as low as $6.6 \%$ in the oviductal fluidic environment.

In another example, the effects of Ach concentration and temperature gradient on high-quality mouse sperm sorting were investigated using an indium tin oxide (ITO) microheater in a single microfluidic channel [91]. The combination of chemotaxis and thermotaxis strategies resulted in a better isolation behavior and a more precise selection of capacitated sperms. Figure $3 \mathrm{C}$ shows that the addition of the Ach solution to the outlet leads to a chemical gradient along the channel. In this device, motile sperms were reported to migrate to the outlet when the temperature gradient reached $0.154{ }^{\circ} \mathrm{C} / \mathrm{mm}$ (the temperature started at $35^{\circ} \mathrm{C}$ in the inlet and reached $37^{\circ} \mathrm{C}$ at the outlet). 
A

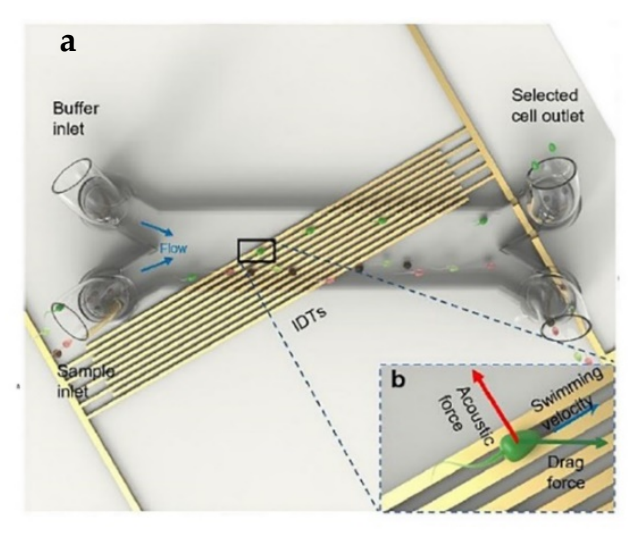

b

Motile sperm response to acoustic field
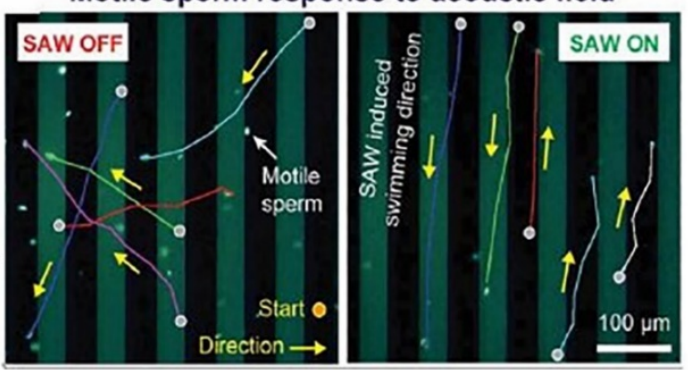
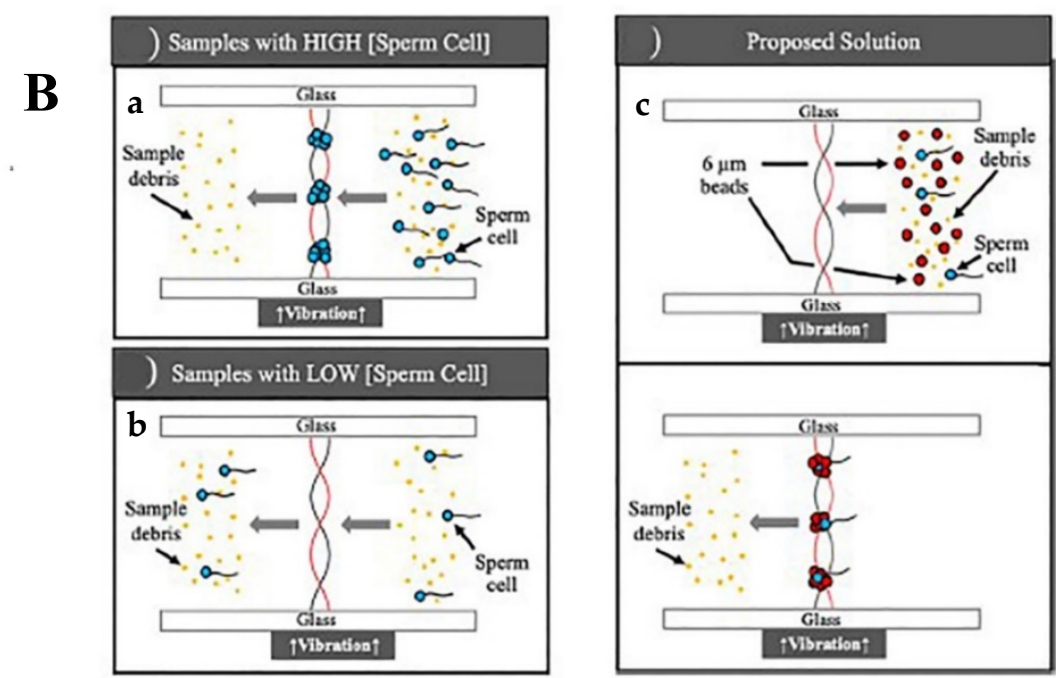

C

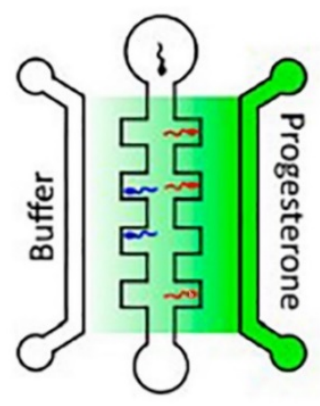

D
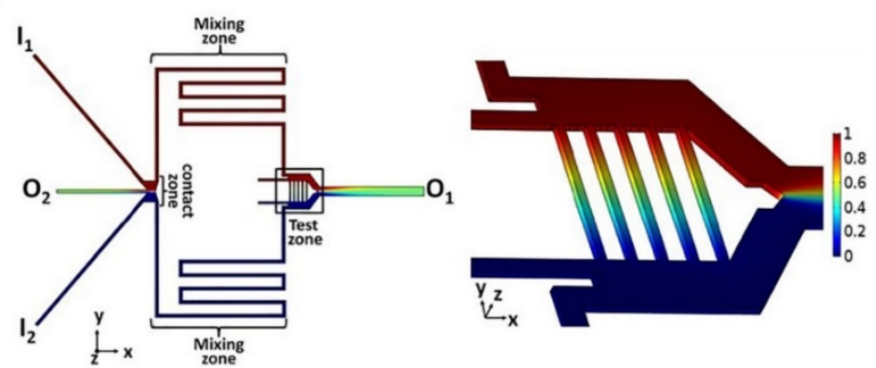

Figure 2. Active design of microfluidic chips for sperm sorting. (A) Schematic view of a SAW-based microfluidic sperm sorting device: (a) lateral displacement of normal and motile sperms as the acoustic wave overcomes the viscous dragging forces and (b) motile sperms respond to SAW and change their swimming path [78]. (B) Schematic view of a BAW-based microfluidic sperm sorting device: (a) motile sperms from a high-concentrated sperm sample are trapped in the acoustic node, (b) no trapping occurs in a low-concentration sperm sample, (c) proposed solution of polymeric beads (with similar size to morphologically normal sperms) enhances the efficiency of sperm trapping in a low-concentration sperm sample [84]. (C) A flow-free microfluidic device to sort capacitated sperms based on their chemotaxis response to a progesterone concentration gradient [87]. (D) A chemotaxis-based sperm sorting microfluidic device with constant acetylcholine (Ach) and rat oviductal fluid concentration gradient in a stationary fluidic environment [90]. Figures reprinted with permissions. 
Table 2. Active strategies that were reported for sperm sorting.

\begin{tabular}{|c|c|c|c|c|c|}
\hline Sorting Strategy & Parameter(s) & Advantages & Disadvantages & Significance & Ref. \\
\hline \multirow[t]{2}{*}{ Acoustic waves } & $\begin{array}{l}\text {-Surface acoustic wave } \\
\text {-Sperm size } \\
\text {-Motility pattern }\end{array}$ & $\begin{array}{l}\text {-External sorting } \\
\text {-Precise control of sperm } \\
\text { selection process }\end{array}$ & $\begin{array}{l}\text {-Invasive } \\
\text {-Need for additional } \\
\text { equipment }\end{array}$ & $\begin{array}{l}\text {-Operation time: } 50 \mathrm{~min} \\
\text {-Throughput: } \\
\text { 60,000 sperms / cycle } \\
\text {-Vitality: } 50 \% \\
\text {-Progressive motility: } 60 \% \\
\text {-DNA integrity: }>38 \% \\
\text {-Swimming velocity: } 64 \%\end{array}$ & [78] \\
\hline & $\begin{array}{l}\text {-Bulk acoustic wave } \\
\text {-Pressure distribution } \\
\text { through the fluid } \\
\text {-Addition of } \\
\text { polystyrene beads }\end{array}$ & $\begin{array}{l}\text {-Isolates scarce number of } \\
\text { sperms from female } \\
\text { DNA samples }\end{array}$ & $\begin{array}{l}\text {-Lower power compared to } \\
\text { surface acoustic wave } \\
\text {-Invasive } \\
\text {-Need for } \\
\text { additional equipment }\end{array}$ & $\begin{array}{l}\text {-Operation time: } 15 \mathrm{~min} \\
\text {-Particle size of } \\
\text { polystyrene beads: equal } \\
\text { to sperms } \\
\text {-Isolation efficiency: } 85 \%\end{array}$ & [84] \\
\hline \multirow[t]{2}{*}{ Chemotaxis } & $\begin{array}{l}\text {-Progesterone gradient } \\
\text { concentration } \\
\text {-Sperms' chemoattractant } \\
\text { behavior }\end{array}$ & $\begin{array}{l}\text {-Noninvasive } \\
\text {-Biomimetic strategy } \\
\text {-Flow-free }\end{array}$ & -Low efficiency & $\begin{array}{l}\text {-Sperms chemotactic } \\
\text { ratio: } 1.41\end{array}$ & [87] \\
\hline & $\begin{array}{l}\text {-Ach }{ }^{1} \text { and rat oviductal } \\
\text { fluid gradient } \\
\text { concentration } \\
\text {-Sperms' chemoattractant } \\
\text { behavior }\end{array}$ & $\begin{array}{l}\text {-Uniform gradient } \\
\text {-Stationary fluidic } \\
\text { environment } \\
\text {-Biomimetic strategy } \\
\text {-Eliminate rheotactic and } \\
\text { chemokinetic behavior of } \\
\text { sperms as selection } \\
\text { criteria }\end{array}$ & -Low efficiency & $\begin{array}{l}\text {-Improved number of } \\
\text { entered sperms by } \\
\text { increasing ACh } \\
\text { concentration: } 20 \% \\
\text {-Sperm population with } \\
\text { chemotactic behavior in } \\
\text { ACh-rich environment: } \\
8.5 \% \\
\text {-Sperm population with } \\
\text { chemotactic behavior in } \\
\text { oviductal fluidic } \\
\text { environment: } 6.6 \%\end{array}$ & [90] \\
\hline $\begin{array}{l}\text { Chemotaxis and } \\
\text { thermotaxis }\end{array}$ & $\begin{array}{l}\text {-ACh gradient } \\
\text { concentration } \\
\text {-Temperature gradient } \\
\text {-Sperms' chemoattractant } \\
\text { and thermoattractant } \\
\text { behavior }\end{array}$ & $\begin{array}{l}\text {-Flow-free } \\
\text {-Biomimetic strategy }\end{array}$ & $\begin{array}{l}\text {-Complicated chip design } \\
\text { and fabrication due to } \\
\text { complex high-aspect-ratio } \\
\text { geometry } \\
\text {-Need of additional } \\
\text { structural features }\end{array}$ & $\begin{array}{l}\text {-Optimized temperature } \\
\text { gradient: } 0.154^{\circ} \mathrm{C} / \mathrm{mm} \\
\text { from } 35 \text { to } 37^{\circ} \mathrm{C}\end{array}$ & [91] \\
\hline
\end{tabular}

${ }^{1}$ ACh: acetylcholine.

\subsection{Point-of-Care (PoC) Microfluidic Devices for Sperm Sorting}

More than 30 million men worldwide suffer from male infertility. Semen analysis is identified as an important diagnostic strategy; however, the currently available methods are expensive, labor-intensive, and technician-dependent. In order to address such issues, several innovative and advanced $\mathrm{PoC}$ devices have been developed by integrating microfluidics, electronics, and smartphone-based technologies for rapid, fully automated, and inexpensive semen analysis at the patients' side [92,93]. Such PoC devices, similar to others, can help to boost the diagnostic and treatment of infertility and sperm analysis. Some of the examples of such devices are as follows.

Several paper-based microfluidic devices for sperm analysis are reported in the literature; however, they are not intended to be used for sperm sorting. For example, a couple of MTT (3-(4,5-Dimethylthiazol-2-yl)-2,5-diphenyltetrazolium bromide)-based colorimetric paper assays using smartphone imaging were developed to assess total motile sperm concentration at home [94-96]. Moreover, Nosrati and colleagues developed a novel paper-based sperm chromatin integrity analysis, which measured DNA fragmentation and packaging [97]. They used wax patterning on nitrocellulose paper to create two circular reservoirs connected via a channel. As seen in Figure 3A, the sample channel created an ion concentration polarization (ICP) separation by applying voltages in order to measure the integrity of DNA in the prepared sperms (dilution and lysing). DNA integrity was measured based on the ratio of ssDNA to total DNA, as well as high-DNA-stainability markers. This simple, fast, inexpensive, and portable device showed comparable performance to the gold standard sperm chromatin structure assay. 
There are few microfluidics POC devices that perform sperm sorting along with sperm analysis. One example is a disposable portable microfluidic device to measure the sperm concentration and motility that changes a smartphone into a microscope (Figure 3B) [92]. The findings indicate that this smartphone-based platform is capable of detecting abnormal semen in terms of low sperm concentration $(<15$ million sperms $/ \mathrm{mL})$ and low motility $(<40 \%)$ in fresh, unprocessed, and unwashed seminal samples with high accuracy of about $98 \%$ in a short time $(<5 \mathrm{~s})$.

Another smartphone-based semen-analyzing platform was developed for a comprehensive and fast semen analysis through measuring its viability, DNA integrity, and maturity [93]. This super-fast (less than $1 \mathrm{~min}$ ) platform benefits from an image processing algorithm and has a low analysis cost of 5 USD. Although this platform was only tested in laboratories, the developers are confident that with minor modifications, it can be used at home or as a remote-controlled device.

In another smartphone-based sperm assay, a disposable microfluidic chip was developed to help sort and count motile sperms. The turnaround time of this passive sorting chip was only 5 to $10 \mathrm{~min}$ and could display the results if connected to a smartphone. In terms of performance, the chip had a good agreement with existing commercial total motile sperm counters. The chip took advantage of a novel special design, which consisted of a feedback channel, a single inlet, and no outlet. This significantly reduced the unwanted evaporation of the media, preventing additional fluid flow in the chip [98].

Recently, a portable sperm cell purification chip was developed based on continuous flow acoustophoretic separation of sperm cells [99]. The portable device was designed to be used in crime scenes to separate sperms from the original forensic sample mixtures and identify the suspect. The continuous flow two-step acoustic cell separation strategy was applied in the device to separate the sperms from epithelial cells and to remove the contaminants and debris without any need for a cell lysis buffer. Figure 3C displays the chip design and its working mechanism while showing the acoustofluidic transducer at the bottom. Such a portable, automated, fast, efficient, and inexpensive test showed comparable performance to that of conventional laboratory analysis techniques on forensic samples. The main advantages were the recovery rate of sperm cells of about 88 percent, the purity of 96 percent, and the turnaround time of $35 \mathrm{~min}$ for a $100 \mu \mathrm{L}$ sample. It can also be integrated with downstream genetic analysis modules, which is an important feature for forensic applications. 


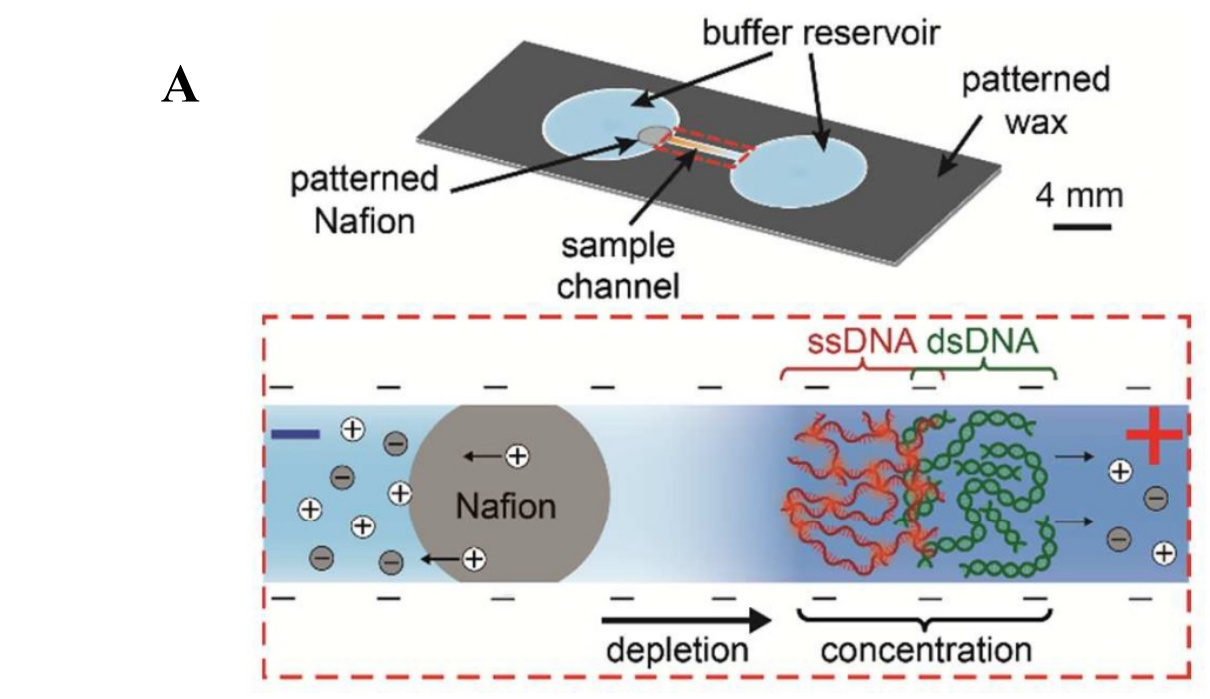

B



C
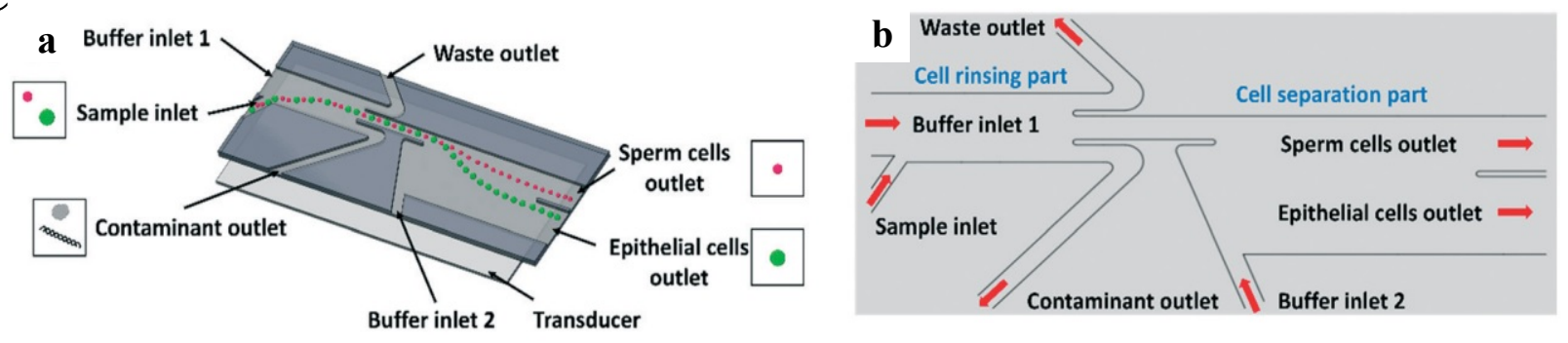

Figure 3. (A) Paper-based sperm DNA integrity assay (measures DNA fragmentation and packaging) using a visual colorimetric detection method and an ion concentration polarization (ICP) separation technique [97]. (B) A disposable microfluidic device that can be inserted into a smartphone-based platform to analyze seminal samples for point-of-care male infertility diagnostics [92]. (C) (a) Chip scheme and (b) working mechanism of the novel portable sperm cell purification assay based on continuous flow acoustophoretic separation of sperm cells from epithelial cells and debris at a sexual assault crime scene [99]. Figures reprinted with permissions.

\section{Conclusions and Future Directions}

Microfluidic-based devices have shown promising results for sorting spermatozoa using various on-chip mechanical and chemical stimuli. Applying fluid mechanics features at the microscale to manipulate the efficient movement of only motile sperms is the core of such approaches. Both stimuli- and non-stimuli- (mechanical) based methods have their advantages and disadvantages. This is why the stimuli should be selected in a way that 
would not harm the sperms. These conditions are well explained in the literature and therefore should be used as a guideline in selecting the stimuli. Moreover, active-based sorters need a module to apply the stimulant. This makes the design more complicated due to the complex high-aspect-ratio geometry in the microstructures with micropillars or microwalls that affect the size, price, and portability of the device. Those devices relying on chemotaxis and thermotaxis, especially, need reservoirs for the reagents and special training to use them. Passive methods, on the other hand, are less complicated in this regard but, at the same time, not as efficient as active methods and therefore have limited potential applications for sperm sorting. Most PoC devices are designed to benefit from a phone camera as an imaging system to facilitate the design. Therefore, taking all these into account, the final decision on which technique to use should be determined based on the application and considering the circumstance.

Considering the above-mentioned promising results, such labs-on-chips are expected to soon become more commonly used in infertility treatment centers around the world. However, they are expected to evolve in two main aspects. One is the application of more complex flow manipulation strategies through implementing two or more sorting systems in order to improve the quality and specificity of the process. This can be achieved, for instance, through the simultaneous application of acoustic waves and chemical attraction methods. Such chips would require a precise design to avoid any possible damage to the sperm. However, such modifications might increase the overall cost of the tool but would allow for improving the sorting efficacy. Exploring new stimulants, such as electrical stimulants, and the use of nanoparticles are other options.

An ideal such lab-on-a-chip should be capable of efficient sorting, along with real-time monitoring and quality control of the IVF steps in an automated manner. The need for automation and serial sample manipulation while reducing the number of preparation steps and the cost is therefore another aspect to be addressed in the future. Such improvements can be achieved through combining the sorting, oocyte culturing, and conception steps all in a single or interconnected chip. On-chip flow manipulations can be controlled using programmable on-chip micropumps and microvalves [100,101]. In addition, artificial intelligence and machine learning [102] have a high potential to be used in such chips or for analysis purposes.

Funding: This research received no external funding.

Institutional Review Board Statement: Not applicable.

Informed Consent Statement: Not applicable.

Data Availability Statement: Not applicable.

Conflicts of Interest: The authors declare no conflict of interest.

\section{References}

1. Samuel, R.; Feng, H.; Jafek, A.; Despain, D.; Jenkins, T.; Gale, B. Microfluidic-Based sperm sorting \& analysis for treatment of male infertility. Transl. Androl. Urol. 2018, 7, S336.

2. Ortseifen, V.; Viefhues, M.; Wobbe, L.; Grünberger, A. Microfluidics for Biotechnology: Bridging Gaps to Foster Microfluidic Applications. Front. Bioeng. Biotechnol. 2020, 8, 1324. [CrossRef]

3. Nikshad, A.; Aghlmandi, A.; Safaralizadeh, R.; Aghebati-Maleki, L.; Warkiani, M.E.; Khiavi, F.M.; Yousefi, M. Advances of microfluidic technology in reproductive biology. Life Sci. 2021, 265, 118767. [CrossRef]

4. Sequeira, R.C.; Criswell, T.; Atala, A.; Yoo, J.J. Microfluidic systems for assisted reproductive technologies: Advantages and potential applications. Tissue Eng. Regen. Med. 2020, 17, 787-800. [CrossRef] [PubMed]

5. Xu, L.; Shoaie, N.; Jahanpeyma, F.; Zhao, J.; Azimzadeh, M.; Al-Jamal, K.T. Optical, electrochemical and electrical (nano)biosensors for detection of exosomes: A comprehensive overview. Biosens. Bioelectron. 2020, 161. [CrossRef] [PubMed]

6. Manafi, N.; Shokri, F.; Achberger, K.; Hirayama, M.; Mohammadi, M.H.; Noorizadeh, F.; Hong, J.; Liebau, S.; Tsuji, T.; Quinn, P.M.J.; et al. Organoids and organ chips in ophthalmology. Ocul. Surf. 2021, 19, 1-15. [CrossRef] [PubMed]

7. Topkaya, S.N.; Azimzadeh, M.; Ozsoz, M. Electrochemical biosensors for cancer biomarkers detection: Recent advances and challenges. Electroanalysis 2016, 28, 1402-1419. [CrossRef] 
8. Ahmed, I.; Akram, Z.; Bule, M.H.; Iqbal, H.M.N. Advancements and potential applications of microfluidic approaches-A review. Chemosensors 2018, 6, 46. [CrossRef]

9. Tzouanas, C.; Lim, J.S.Y.; Wen, Y.; Thiery, J.P.; Khoo, B.L. Microdevices for non-invasive detection of bladder cancer. Chemosensors 2017, 5, 30. [CrossRef]

10. Khashayar, P.; Amoabediny, G.; Larijani, B.; Hosseini, M.; Verplancke, R.; Schaubroeck, D.; Van Put, S.; Razi, F.; De Keersmaecker M.; Adriaens, A.; et al. A Multiplexed microfluidic platform for bone marker measurement: A Proof-of-concept. Micromachines 2017, 8, 133. [CrossRef]

11. Bisht, S.; Faiq, M.; Tolahunase, M.; Dada, R. Oxidative stress and male infertility. Nat. Rev. Urol. 2017, 14, 470-485. [CrossRef]

12. Marzano, G.; Chiriacò, M.S.; Primiceri, E.; Dell'Aquila, M.E.; Ramalho-Santos, J.; Zara, V.; Ferramosca, A.; Maruccio, G. Sperm selection in assisted reproduction: A review of established methods and cutting-edge possibilities. Biotechnol. Adv. 2020, 40, 107498. [CrossRef] [PubMed]

13. Moore, H.; Aflatoonian, B. From stem cells to spermatozoa and back. Soc. Reprod. Fertil. Suppl. 2007, 65, 19-32.

14. Cardona Barberán, A.; Boel, A.; Vanden Meerschaut, F.; Stoop, D.; Heindryckx, B. Diagnosis and treatment of male infertilityrelated fertilization failure. J. Clin. Med. 2020, 9, 3899. [CrossRef]

15. Omidi, M.; Aflatoonian, B.; Tahajjodi, S.S.; Khalili, M.A. Attempts for generation of embryonic stem cells from human embryos following in vitro embryo twinning. Stem Cells Dev. 2019, 28, 303-309. [CrossRef] [PubMed]

16. Aflatoonian, B.; Ruban, L.; Jones, M.; Aflatoonian, R.; Fazeli, A.; Moore, H.D. In vitro post-meiotic germ cell development from human embryonic stem cells. Hum. Reprod. 2009, 24, 3150-3159. [CrossRef] [PubMed]

17. Akyash, F.; Aflatoonian, R.; Golzadeh, J.; Tahajjodi, S.; Moore, H.; Aflatoonian, B. Testicular sperm extraction derived cells conditioned medium as an in vitro niche supports germ cells development from human embryonic stem cells. In Proceedings of the 35th Annual Meeting of the European Society for Human Reproduction and Embryology, Vienna, Austria, 23-26 June 2019.

18. Adib, M.; Seifati, S.M.; Ashkezari, M.D.; Akyash, F.; Khoradmehr, A.; Aflatoonian, B. Effect of human testicular cells conditioned medium on in vitro maturation and morphology of mouse oocytes. Int. J. Fertil. Steril. 2020, 14, 176-184. [CrossRef]

19. Huleihel, M.; Lunenfeld, E. Approaches and technologies in male fertility preservation. Int. J. Mol. Sci. 2020, 21, 5471. [CrossRef]

20. Sakkas, D.; Ramalingam, M.; Garrido, N.; Barratt, C.L.R. Sperm selection in natural conception: What can we learn from Mother Nature to improve assisted reproduction outcomes? Hum. Reprod. Update 2015, 21, 711-726. [CrossRef]

21. Alvarez-Rodriguez, M.; Martinez, C.A.; Wright, D.; Rodriguez-Martinez, H. Does the act of copulation per se, without considering seminal deposition, change the expression of genes in the porcine female genital tract? Int. J. Mol. Sci. 2020, 21, 5477. [CrossRef]

22. Lin, D.; Ran, J.; Zhu, S.; Quan, S.; Ye, B.; Yu, A.; Kang, Y.; Lin, Y. Effect of GOLPH3 on cumulus granulosa cell apoptosis and ICSI pregnancy outcomes. Sci. Rep. 2017, 7, 7863. [CrossRef]

23. Tahajjodi, S.; Farashahi Yazd, E.; Aflatoonian, R.; Agharahimi, A.; Hajizadeh-Tafti, F.; Akyash, F.; Moore, H.; Aflatoonian, B. Cumulus cells conditioned medium as an in vitro niche for differentiation of human embryonic stem cells to female germ cells. In Proceedings of the 35th Annual Meeting of the European Society for Human Reproduction and Embryology, Vienna, Austria, 23-26 June 2019.

24. Tahajjodi, S.S.; Yazd, E.F.; Agha-Rahimi, A.; Aflatoonian, R.; Khalili, M.A.; Mohammadi, M.; Aflatoonian, B. Biological and physiological characteristics of human cumulus cells in adherent culture condition. Int. J. Reprod. Biomed. 2020, 18, 1-10. [CrossRef]

25. Jin, R.; Bao, J.; Tang, D.; Liu, F.; Wang, G.; Zhao, Y.; Bai, G.; Liu, Y.; Wang, Y.; Liu, L.; et al. Outcomes of intracytoplasmic sperm injection using the zona pellucida-bound sperm or manually selected sperm. J. Assist. Reprod. Genet. 2016, 33, 597-601. [CrossRef] [PubMed]

26. Izadi, M.; Khalili, M.A.; Salehi-Abargouei, A.; Rezvani, M.E.; Aflatoonian, B. Use of zona pellucida-bound sperm as a natural selection in improvement of ICSI outcomes: A systematic review and meta-analysis. Andrologia 2020, 7, e14022.

27. Fitzpatrick, J.L.; Lüpold, S. Sexual selection and the evolution of sperm quality. Mol. Hum. Reprod. 2014, 20, 1180-1189. [CrossRef] [PubMed]

28. Tomlinson, M.; Lewis, S.; Morroll, D. Sperm quality and its relationship to natural and assisted conception: British Fertility Society Guidelines for practice. Hum. Fertil. 2013, 16, 175-193. [CrossRef]

29. Barratt, C.L.R.; Björndahl, L.; De Jonge, C.J.; Lamb, D.J.; Martini, F.O.; McLachlan, R.; Oates, R.D.; van der Poel, S.; John, B.S.; Sigman, M.; et al. The diagnosis of male infertility: An analysis of the evidence to support the development of global WHO guidance-challenges and future research opportunities. Hum. Reprod. Update 2017, 23, 660-680. [CrossRef]

30. Nosrati, R.; Vollmer, M.; Eamer, L.; San Gabriel, M.C.; Zeidan, K.; Zini, A.; Sinton, D. Rapid selection of sperm with high DNA integrity. Lab Chip 2014, 14, 1142-1150. [CrossRef]

31. Nosrati, R.; Graham, P.J.; Zhang, B.; Riordon, J.; Lagunov, A.; Hannam, T.G.; Escobedo, C.; Jarvi, K.; Sinton, D. Microfluidics for sperm analysis and selection. Nat. Rev. Urol. 2017, 14, 707-730. [CrossRef]

32. Zhang, B.; Yin, T.L.; Yang, J. A novel microfluidic device for selecting human sperm to increase the proportion of morphologically normal, motile sperm with uncompromised DNA integrity. Anal. Methods 2015, 7, 5981-5988. [CrossRef]

33. de Wagenaar, B.; Berendsen, J.T.W.; Bomer, J.G.; Olthuis, W.; van den Berg, A.; Segerink, L.I. Microfluidic single sperm entrapment and analysis. Lab Chip 2015, 15, 1294-1301. [CrossRef]

34. Shirota, K.; Yotsumoto, F.; Itoh, H.; Obama, H.; Hidaka, N.; Nakajima, K.; Miyamoto, S. Separation efficiency of a microfluidic sperm sorter to minimize sperm DNA damage. Fertil. Steril. 2016, 105, 315-321.e1. [CrossRef] 
35. Vaughan, D.A.; Sakkas, D. Sperm selection methods in the 21. Biol. Reprod. 2019, 101, 1076-1082. [CrossRef]

36. Sharma, S.; Venzac, B.; Burgers, T.; Le Gac, S.; Schlatt, S. Microfluidics in male reproduction: Is ex vivo culture of primate testis tissue a future strategy 2 for ART or toxicology research? Mol. Hum. Reprod. 2020, 26, 179-192. [CrossRef] [PubMed]

37. Swain, J.E.; Lai, D.; Takayama, S.; Smith, G.D. Thinking big by thinking small: Application of microfluidic technology to improve ART. Lab Chip 2013, 13, 1213-1224. [CrossRef] [PubMed]

38. Han, C.; Zhang, Q.; Ma, R.; Xie, L.; Qiu, T.; Wang, L.; Mitchelson, K.; Wang, J.; Huang, G.; Qiao, J.; et al. Integration of single oocyte trapping, in vitrofertilization and embryo culture in a microwell-structured microfluidic device. Lab Chip 2010, 10, $2848-2854$. [CrossRef] [PubMed]

39. Zhao, G.; Zhang, Z.; Zhang, Y.; Chen, Z.; Niu, D.; Cao, Y.; He, X. A microfluidic perfusion approach for on-chip characterization of the transport properties of human oocytes. Lab Chip 2017, 17, 1297-1305. [CrossRef] [PubMed]

40. Clark, S.G.; Haubert, K.; Beebe, D.J.; Ferguson, C.E.; Wheeler, M.B. Reduction of polyspermic penetration using biomimetic microfluidic technology during in vitro fertilization. Lab Chip 2005, 5, 1229-1232. [CrossRef] [PubMed]

41. Zeringue, H.C.; Wheeler, M.B.; Beebe, D.J. A microfluidic method for removal of the zona pellucida from mammalian embryos Lab Chip 2005, 5, 108-110. [CrossRef] [PubMed]

42. Zeringue, H.C.; Beebe, D.J.; Wheeler, M.B. Removal of cumulus from mammalian zygotes using microfluidic techniques. Biomed. Microdevices 2001, 3, 219-224. [CrossRef]

43. Schuster, T.G.; Cho, B.; Keller, L.M.; Takayama, S.; Smith, G.D. Isolation of motile spermatozoa from semen samples using microfluidics. Reprod. Biomed. Online 2003, 7, 75-81. [CrossRef]

44. Beebe, D.J.; Wheeler, M.; Zeringue, H.C.; Walters, E.; Raty, S. Microfluidic technology for assisted reproduction. Theriogenology 2002, 57, 125-135. [CrossRef]

45. McCormack, M.C.; McCallum, S.; Behr, B. A novel microfluidic device for male subfertility screening. J. Urol. 2006, 175, 2223-2227. [CrossRef]

46. Koyama, S.; Amarie, D.; Soini, H.A.; Novotny, M.V.; Jacobson, S.C. Chemotaxis assays of mouse sperm on microfluidic devices. Anal. Chem. 2006, 78, 3354-3359. [CrossRef] [PubMed]

47. Zhang, X.; Khimji, I.; Gurkan, U.A.; Safaee, H.; Catalano, P.N.; Keles, H.O.; Kayaalp, E.; Demirci, U. Lensless imaging for simultaneous microfluidic sperm monitoring and sorting. Lab Chip 2011, 11, 2535-2540. [CrossRef]

48. Lopez-Garcia, M.d.C.; Monson, R.L.; Haubert, K.; Wheeler, M.B.; Beebe, D.J. Sperm motion in a microfluidic fertilization device. Biomed. Microdevices 2008, 10, 709-718. [CrossRef] [PubMed]

49. Cho, B.S.; Schuster, T.G.; Zhu, X.; Chang, D.; Smith, G.D.; Takayama, S. Passively driven integrated microfluidic system for separation of motile sperm. Anal. Chem. 2003, 75, 1671-1675. [CrossRef] [PubMed]

50. Chen, Y.-A.; Huang, Z.-W.; Tsai, F.-S.; Chen, C.-Y.; Lin, C.-M.; Wo, A.M. Analysis of sperm concentration and motility in a microfluidic device. Microfluid. Nanofluidics 2011, 10, 59-67. [CrossRef]

51. Chen, C.-Y.; Chiang, T.-C.; Lin, C.-M.; Lin, S.-S.; Jong, D.-S.; Tsai, V.F.-S.; Hsieh, J.-T.; Wo, A.M. Sperm quality assessment via separation and sedimentation in a microfluidic device. Analyst 2013, 138, 4967-4974. [CrossRef]

52. Xiao, S.; Riordon, J.; Simchi, M.; Lagunov, A.; Hannam, T.; Jarvi, K.; Nosrati, R.; Sinton, D. FertDish: Microfluidic sperm selection-in-a-dish for intracytoplasmic sperm injection. Lab Chip 2021, 21, 775-783. [CrossRef]

53. Knowlton, S.M.; Sadasivam, M.; Tasoglu, S. Microfluidics for sperm research. Trends Biotechnol. 2015, 33, 221-229. [CrossRef] [PubMed]

54. Nakao, S.; Takeo, T.; Watanabe, H.; Kondoh, G.; Nakagata, N. Successful selection of mouse sperm with high viability and fertility using microfluidics chip cell sorter. Sci. Rep. 2020, 10, 8862. [CrossRef] [PubMed]

55. Quinn, M.M.; Jalalian, L.; Ribeiro, S.; Ona, K.; Demirci, U.; Cedars, M.I.; Rosen, M.P. Microfluidic sorting selects sperm for clinical use with reduced DNA damage compared to density gradient centrifugation with swim-up in split semen samples. Hum. Reprod. 2018, 33, 1388-1393. [CrossRef] [PubMed]

56. Phiphattanaphiphop, C.; Leksakul, K.; Phatthanakun, R.; Khamlor, T. A novel microfluidic chip-based sperm-sorting device constructed using design of experiment method. Sci. Rep. 2020, 10, 17143. [CrossRef] [PubMed]

57. Riordon, J.; Tarlan, F.; You, J.B.; Zhang, B.; Graham, P.J.; Kong, T.; Wang, Y.; Lagunov, A.; Hannam, T.; Jarvi, K.; et al. Twodimensional planar swimming selects for high DNA integrity sperm. Lab Chip 2019, 19, 2161-2167. [CrossRef] [PubMed]

58. Zhang, Y.; Xiao, R.-R.; Yin, T.; Zou, W.; Tang, Y.; Ding, J.; Yang, J. Generation of gradients on a microfluidic device: Toward a high-throughput investigation of spermatozoa chemotaxis. PLoS ONE 2015, 10, e0142555. [CrossRef]

59. Suarez, S.S. Mammalian sperm interactions with the female reproductive tract. Cell Tissue Res. 2016, 363, 185-194. [CrossRef]

60. Kashaninejad, N.; Shiddiky, M.J.A.; Nguyen, N. Advances in microfluidics-based assisted reproductive technology: From sperm sorter to reproductive system-on-a-chip. Adv. Biosyst. 2017, 9, 1700197. [CrossRef]

61. Riffell, J.A.; Zimmer, R.K. Sex and flow: The consequences of fluid shear for sperm-egg interactions. J. Exp. Biol. 2007, 210, 3644-3660. [CrossRef]

62. Chinnasamy, T.; Kingsley, J.L.; Inci, F.; Turek, P.J.; Rosen, M.P.; Behr, B.; Tüzel, E.; Demirci, U. Guidance and self-sorting of active swimmers: 3D periodic arrays increase persistence length of human sperm selecting for the fittest. Adv. Sci. 2018, 5, 1700531. [CrossRef]

63. Kaupp, U.B.; Strünker, T. Signaling in sperm: More different than similar. Trends Cell Biol. 2016, 27, 101-109. [CrossRef] [PubMed]

64. Panigrahi, S.B.; Chen, C. Microfluidic retention of progressively motile zebrafish sperms. Lab Chip 2019, 19, 4033-4042. [CrossRef] 
65. Zaferani, M.; Palermo, G.D.; Abbaspourrad, A. Strictures of a microchannel impose fierce competition to select for highly motile sperm. Sci. Adv. 2019, 5, eaav2111. [CrossRef]

66. Suarez, S.S.; Wu, M. Microfluidic devices for the study of sperm migration. Mol. Hum. Reprod. 2017, 23, 227-234. [CrossRef]

67. Miki, K.; Clapham, D.E. Rheotaxis guides mammalian sperm. Curr. Biol. 2013, 23, 443-452. [CrossRef]

68. Eisenbach, M.; Giojalas, L.C. Sperm guidance in mammals-An unpaved road to the egg. Nat. Rev. Mol. Cell Biol. 2006, 7, 276-285. [CrossRef] [PubMed]

69. Wu, J.K.; Chen, P.C.; Lin, Y.N.; Wang, C.W.; Pan, L.C.; Tseng, F.G. High-throughput flowing upstream sperm sorting in a retarding flow field for human semen analysis. Analyst 2017, 142, 938-944. [CrossRef]

70. Zaferani, M.; Cheong, S.H.; Abbaspourrad, A. Rheotaxis-based separation of sperm with progressive motility using a microfluidic corral system. Proc. Natl. Acad. Sci. USA 2018, 115, 8272-8277. [CrossRef] [PubMed]

71. Kang, H.; An, T.; Lee, D.; Kim, B. Gravity and rheotaxis based sperm sorting device employing a cam-actuated pipette mechanism. Rev. Sci. Instrum. 2019, 90. [CrossRef]

72. Hwang, B.; Lee, D.; Hwang, S.J.; Baek, J.H.; Kim, B. Rheotaxis Based High-Throughput Motile Sperm Sorting Device. Int. J. Precis. Eng. Manuf. 2019, 20, 1037-1045. [CrossRef]

73. Suarez, S.S.; Pacey, A.A. Sperm transport in the female reproductive tract. Hum. Reprod. Update 2006, 12, 23-37. [CrossRef] [PubMed]

74. Yan, Y.; Liu, H.; Zhang, B.; Liu, R. A PMMA-based microfluidic device for human sperm evaluation and screening on swimming capability and swimming persistence. Micromachines 2020, 11, 793. [CrossRef] [PubMed]

75. Huang, H.Y.; Lu, C.Y.; Wang, I.W.; Yao, D.J. Motility-driven sperm-sorting microfluidic chip with little cell damage for oligozoospermia patients. Sens. Mater. 2020, 32, 2585-2596. [CrossRef]

76. Huang, H.Y.; Huang, P.W.; Yao, D.J. Enhanced efficiency of sorting sperm motility utilizing a microfluidic chip. Microsyst. Technol. 2017, 23, 305-312. [CrossRef]

77. Nagata, M.P.B.; Endo, K.; Ogata, K.; Yamanaka, K.; Egashira, J.; Katafuchi, N.; Yamanouchi, T.; Matsuda, H.; Goto, Y.; Sakatani, M.; et al. Live births from artificial insemination of microfluidic-sorted bovine spermatozoa characterized by trajectories correlated with fertility. Proc. Natl. Acad. Sci. USA 2018, 115, E3087-E3096. [CrossRef]

78. Gai, J.; Nosrati, R.; Neild, A. High DNA integrity sperm selection using surface acoustic waves. Lab Chip 2020, 20, 4262-4272. [CrossRef]

79. Nguyen, N.-T.; Wereley, S.; Shaegh, S.A.M. Fundamentals and Applications of Microfluidics, 3rd ed.; Artech: Norwood, MA, USA, 2019; ISBN 9781630813659.

80. Lin, S.C.S.; Mao, X.; Huang, T.J. Surface Acoustic Wave (SAW) acoustophoresis: Now and beyond. Lab Chip 2012, 12, 2766-2770. [CrossRef]

81. Neild, A.; Oberti, S.; Dual, J. Design, modeling and characterization of microfluidic devices for ultrasonic manipulation. Sens. Actuators B Chem. 2007, 121, 452-461. [CrossRef]

82. Ding, X.; Li, P.; Lin, S.C.S.; Stratton, Z.S.; Nama, N.; Guo, F.; Slotcavage, D.; Mao, X.; Shi, J.; Costanzo, F.; et al. Surface acoustic wave microfluidics. Lab Chip 2013, 13, 3626-3649. [CrossRef]

83. Clark, C.P.; Xu, K.; Scott, O.; Hickey, J.; Tsuei, A.C.; Jackson, K.; Landers, J.P. Acoustic trapping of sperm cells from mock sexual assault samples. Forensic Sci. Int. Genet. 2019, 41, 42-49. [CrossRef]

84. Xu, K.; Clark, C.P.; Poe, B.L.; Lounsbury, J.A.; Nilsson, J.; Laurell, T.; Landers, J.P. Isolation of a low number of sperm cells from female DNA in a glass-PDMS-glass microchip via bead-assisted acoustic differential extraction. Anal. Chem. 2019, 91, $2186-2191$. [CrossRef]

85. Bahat, A.; Eisenbach, M. Sperm thermotaxis. Mol. Cell. Endocrinol. 2006, 252, 115-119. [CrossRef] [PubMed]

86. Pérez-Cerezales, S.; Laguna-Barraza, R.; De Castro, A.C.; Sánchez-Calabuig, M.J.; Cano-Oliva, E.; De Castro-Pita, F.J.; MontoroBuils, L.; Pericuesta, E.; Fernández-González, R.; Gutiérrez-Adán, A. Sperm selection by thermotaxis improves ICSI outcome in mice. Sci. Rep. 2018, 8, 2902. [CrossRef] [PubMed]

87. Berendsen, J.T.W.; Kruit, S.A.; Atak, N.; Willink, E.; Segerink, L.I. Flow-free microfluidic device for quantifying chemotaxis in spermatozoa. Anal. Chem. 2020, 92, 3302-3306. [CrossRef]

88. EL-sherry, T.M.; Abdel-Ghani, M.A.; Mahmoud, G.B.; Ezzat, A.A. Kisspeptin injection improved the semen characteristics and sperm rheotaxis in Ossimi ram. Reprod. Domest. Anim. 2020, 55, 240-247. [CrossRef]

89. Li, Z.; Liu, W.; Qiu, T.; Xie, L.; Chen, W.; Liu, R.; Lu, Y.; Mitchelson, K.; Wang, J.; Qiao, J.; et al. The construction of an interfacial valve-based microfluidic chip for thermotaxis evaluation of human sperm. Biomicrofluidics 2014, 8, 024102. [CrossRef] [PubMed]

90. Bhagwat, S.; Sontakke, S.; Deekshith, K.; Parte, P.; Jadhav, S. Chemotactic behavior of spermatozoa captured using a microfluidic chip. Biomicrofluidics 2018, 12, 024112. [CrossRef]

91. Ko, Y.J.; Maeng, J.H.; Hwang, S.Y.; Ahn, Y. Design, fabrication, and testing of a microfluidic device for thermotaxis and chemotaxis assays of sperm. SLAS Technol. 2018, 23, 507-515. [CrossRef]

92. Kanakasabapathy, M.K.; Sadasivam, M.; Singh, A.; Preston, C.; Thirumalaraju, P.; Venkataraman, M.; Bormann, C.L.; Draz, M.S.; Petrozza, J.C.; Shafiee, H. An automated smartphone-based diagnostic assay for point-of-care semen analysis. Sci. Transl. Med. 2017, 7863, eaai7863. [CrossRef] 
93. Dimitriadis, I.; Bormann, C.L.; Kanakasabapathy, M.K.; Thirumalaraju, P.; Id, H.K.; Yogesh, V.; Gudipati, N. Automated smartphone-based system for measuring sperm viability, DNA fragmentation, and hyaluronic binding assay score. PLoS ONE 2019, 14, e0212562. [CrossRef]

94. Nosrati, R.; Gong, M.M.; Gabriel, M.C.S.; Pedraza, C.E.; Zini, A.; Sinton, D. Paper-based quantification of male fertility potential. Clin. Chem. 2016, 62, 458-465. [CrossRef] [PubMed]

95. Matsuura, K.; Huang, H.W.; Chen, M.C.; Chen, Y.; Cheng, C.M. Relationship between porcine sperm motility and sperm enzymatic activity using paper-based devices. Sci. Rep. 2017, 7, 46213. [CrossRef]

96. Tsao, Y.T.; Yang, C.Y.; Wen, Y.C.; Chang, T.C.; Matsuura, K.; Chen, Y.; Cheng, C.M. Point-of-care semen analysis of patients with infertility via smartphone and colorimetric paper-based diagnostic device. Bioeng. Transl. Med. 2021, 6, e10176. [CrossRef]

97. Nosrati, R.; Gong, M.M.; San Gabriel, M.C.; Zini, A.; Sinton, D. Paper-based sperm DNA integrity analysis. Anal. Methods 2016, 8, 6260-6264. [CrossRef]

98. Kim, Y.; Chun, K. New disposable microfluidic chip without evaporation effect for semen analysis in clinics and homes. Microsyst. Technol. 2020, 26, 647-655. [CrossRef]

99. Sun, K.; Wang, H.; Wang, L.; Lu, Y.; Liu, R.; Liu, P.; Cheng, J. A portable sperm cell purification instrument based on continuous flow acoustophoretic separation of sperm cells for on-site forensic sample pretreatment. Lab Chip 2021, 21, 933-941. [CrossRef] [PubMed]

100. Banejad, A.; Passandideh-Fard, M.; Niknam, H.; Mirshojaeian Hosseini, M.J.; Mousavi Shaegh, S.A. Design, fabrication and experimental characterization of whole-thermoplastic microvalves and micropumps having micromilled liquid channels of rectangular and half-elliptical cross-sections. Sens. Actuators A Phys. 2020, 301, 111713. [CrossRef]

101. Shaegh, S.A.M.; Pourmand, A.; Nabavinia, M.; Avci, H.; Tamayol, A.; Mostafalu, P.; Ghavifekr, H.B.; Aghdam, E.N.; Dokmeci, M.R.; Khademhosseini, A.; et al. Rapid prototyping of whole-thermoplastic microfluidics with built-in microvalves using laser ablation and thermal fusion bonding. Sens. Actuators B Chem. 2018, 255, 100-109. [CrossRef]

102. Annabestani, M.; Shaegh, A.M.; Esmaeili-Dokht, P.; Fardmanesh, M. An intelligent machine learning-based sheath-free microfluidic impedance flow cytometer. In Proceedings of the 2020 10th International Conference on Computer and Knowledge Engineering (ICCKE), Mashhad, Iran, 29-30 October 2020; pp. 284-288. 